\title{
Daniela Manetti*
}

\section{Hippon of Croton (or Samos) from Aristotle to the Anonymus Londiniensis: medicine and research on nature}

\author{
https://doi.org/10.1515/tc-2020-0018
}

\begin{abstract}
Even though Hippon is a minor figure among the so-called Presocratics, a new analysis of some of his fragments confirms that he was a famous and valuable scientist, who explored nature, starting from the vegetal world (botany). He assumed it as a model also for animal and human physiology. The passages examined do him justice against the contempt expressed by Aristotle.
\end{abstract}

Keywords: Hippon, Aristotle, Theophrastus, human physiology, botany.

Hippon is defined as a minor figure among the so-called Presocratics. By W. Guthrie he is said to be an "eclectic", a label which usually marks those thinkers who are not considered valuable or original, as such also reminding us of his problematic classification as a Pythagorean. Hippon is consequently barely named in the standard reference work The Presocratic Philosophers by Kirk/Raven/Schofield. ${ }^{1}$ Nevertheless, some clues suggest that the impact of Hippon's work and thought on the fifth- and fourth-century Greek cultural landscape was far from being negligible. ${ }^{2}$ In this article I suggest that after a new detailed analysis of some of his fragments a plausible consistency emerges in Hippon's thought that would account in some way for his apparent great fame in Athens at the middle of the fifth century.

Hippon is included in the catalogue of Pythagoreans and said to be a native of Samos (A 1, like Pythagoras, source Aristoxenus - via Censor. and Iamblichus, 58

1 Kirk/Raven/Schofield 1983, $91 \mathrm{n}$.

2 After the classic reference work, Die Fragmente der Vorsokratiker: griechisch und deutsch by H. Diels / W. Kranz, I, 1951, 385-389, now we can read Hippon's fragments in the recently published Early Greek Philosophy by A. Laks / G.W. Most, Harvard University Press, Cambridge Mass. 2016, vol. V 2 [24], 772-801, with a new presentation of the testimonies (from now on LM). For a short bibliography, see Manetti 1982, 455-456; Manetti 1989, 111; Narcy 2000, 799-801, and more recently Zhmud 2012, 127-128.

*Corresponding author: Daniela Manetti, Università di Firenze, Dipartimento di Lettere e Filosofia, Florence, Italy, E-Mail: daniela.manetti@unifi.it

Ә Open Access. (C) 2020 Manetti, published by De Gruyter. (c) BY This work is licensed under the Creative Commons Attribution 4.0 International License. 
A, I 447, 13 DK), or Metapontum (Censor. A 1, like Hippasos), or Croton (An. Lond. A 11, like Alcmaeon, Democedes, and Philolaos), or Rhegium (Sext. Emp. A $1=$ A5). ${ }^{3}$ Confusion about the birthplace of many Pythagoreans is seen frequently in Aristoxenus, who is our ultimate source: for example, Brontinus is similarly said to be from Metapontum (Iambl. A1 DK), or Croton (D.L. A 1 DK). As for Hippon, some confusion both about his birthplace and doctrines must have arisen with the almost homonymous Pythagorean, Hippasus of Metapontum. ${ }^{4}$ Indeed, it is impossible to identify specifically Pythagorean features in Hippon's thought, unless the importance of the number seven in his embryology (A16 DK, Censor.) is to be considered highly significant, which is very doubtful. ${ }^{5}$

Hippon's traditional connection with the Pythagorean school is based on his birthplace, which, though controversial, was most probably in Magna Graecia, where he must have lived at least for a period. But, be he a Pythagorean or not, Hippon's fame made its way well beyond the Pythagorean communities of southern Italy and into the heart of Greece. Indeed, we can be sure that he was very well known in Athens around $430 \mathrm{BC}$, because according to a scholion to Aristophanes' Clouds, $94 \mathrm{ff}$., he was satirized both in this play and previously by Cratinus in his play Panoptai (38 A 2 DK = Dram. T 15-16 LM) in 435-431 BC. ${ }^{6}$ Like other philosophers, he was apparently labelled an 'atheist' in Athens for his doctrines, ${ }^{7}$ probably just because of the treatment he was subjected to by the comic poets. ${ }^{8}$ From this information we are able to draw the conclusion that in the middle of the fifth century BC he spent some time in Athens, where he let his doctrines be known and circulated his writings. Indeed, the mobility of ancient intellectuals, philosophers and physicians in the fifth and fourth centuries is a well-known fact.

\section{See P 1-6 LM.}

4 On biographical aspects also playing a role in the classification of thinkers as Pythagorean in Aristoxenus' work, see Centrone 1996, 8-12; see also Zhmud 2012, 127-128. Concerning the confusion about his doctrines, I am alluding to the view that Hippon considered the constituents of the cosmos to be water and fire, as attested by Hippolytus (A3 DK = D1 LM) and Sextus Empiricus (A5 DK = D4 LM, see also Ioannes Diac. in A6 DK = D5 LM, which deems the earth to be the principle in Hippon). Olivieri 1919, 151, concludes that Sextus Empiricus and Hippolytus confused the theories of two thinkers, Hippon (water) and Hippasus (fire). However, this information involves the problem of the possible existence of different links related to Hippon in ancient doxography. This subject deserves an appropriate study which I am not able to do now.

5 Erhard 1939, 328, sees in Hippon "die Zahlenmystik des Pythagoras". Similarities with the Pythagorean tendency to make classifications by contraries are inferred by Repici 2000, 64-65 nn.; Zhmud 2012, 109 n. 22, is more positive, whereas there are doubts in Laks/Most 2016, V 2, 772. 6 As per the scholion ad loc.: there has been some debate about the identity of the author satyrized in Aristophanes' parody, see Olivieri 1919, $154 \mathrm{f}$.

7 A4, A6, A8, B2, B3 DK (= R 3-8 LM).

8 See the most famous case of Socrates in The Clouds by Aristophanes. 
What is certain is that Hippon's book (or books) was (or were) present in the Lyceum in the fourth century, because both Theophrastus quotes him in the Historia Plantarum and the Aristotelian doxography on the causes of disease by the so-called Anonymus Londiniensis, which dates back to the early Peripatos, ${ }^{9}$ apparently quotes two books by Hippon too. But the expression used by the Anonymus

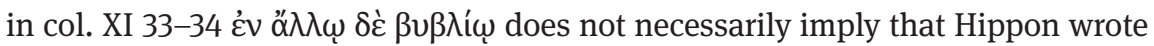
more than one work. Possibly, he wrote a general work on nature in many books (or rolls). A polemic against Empedocles or a similar thinker about the nature of the soul probably also found a place in this work (A4 DK = D 6 LM). The variety of subjects approached by Hippon (botany, human physiology and pathology, embryology, geophysical theory, etc.) is consistent with the character of Greek science in the fifth century BC when no distinction existed between specific areas of knowledge. ${ }^{10}$ Lastly, if a scholion to Iliad $\Phi 195$ is to be credited, Crates may also have read books by Hippon or books about Hippon's theory of the origin of potable waters (38 B 1 DK = D 19 LM)) in Pergamon in the second century BC. ${ }^{11}$

Still, the clues identified about the wide reception of Hippon's work and thought are not fully consistent with the information Aristotle gives us about him. In Metaphysics A 3 he talks of Hippon only to dismiss his membership of the group identified as "most of those who first philosophized" (Metaph. 983b6) over his determination of the material cause.

\section{Arist. Metaph. 983b 18-984a 8 (11 A12, 38 a7 DK)}

All are not agreed, however, as to the number and character of these principles. Thales, the founder of this school of philosophy, says the permanent entity is water (which is why he also propounded that the earth floats on water). Presumably he derived this assumption from seeing that the nutriment of everything is moist and that heat itself is generated from moisture and the animal depends upon it for its life (and that from which a thing is generated is always its first principle). He derived his assumption, then, from this. And also from the fact that seeds of everything have a moist nature, whereas water is the first principle of the nature of moist things. ... It is said that Thales' opinion concerning the first cause was like this, for no one would consider it right to place Hippon in the company of these men on account of the worthlessness of his intellect (trans. Tredennick, Shapiro modified). ${ }^{12}$

9 Manetti 1999, 125-129.

10 Gemelli Marciano 2009.

11 Barney 2012, 92, thinks that Crates too, like Aristotle (see infra), had the Anthology by Hippias as his source.

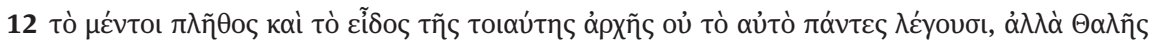

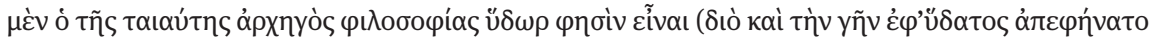

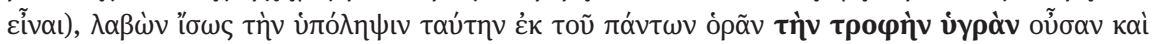

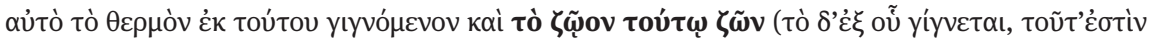

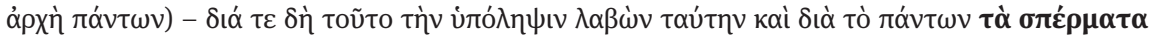


It is generally supposed that when Aristotle gives Thales' opinion about the arche he is depending on a previous doxography (most probably the anthology of related ideas by the sophist Hippias or a work which drew on it) that already linked Hippon with Thales. ${ }^{13}$ Rachel Barney has meticulously analyzed the passage and shares the opinion that the bulk of Aristotle's report on Thales derived from Hippon (or from a source which drew on Hippon) and remarks that Hippon's mention by Aristotle is probably only prompted, in a polemical spirit, by his inclusion in Hippias' doxography. ${ }^{14}$ If this is true, Aristotle would account for the connection between Thales and Hippon stated by Hippias.

Aristotle mentions Hippon only a second time in De Anima 405a 29 - b5 (24 a12 DK, 31 A4, cfr. 38 A10), with the same dismissive tone that marks the distance between Hippon and other philosophers:

\begin{abstract}
Alcmaeon's suppositions about the soul are somewhat similar to these; for he says it is immortal, because it resembles immortal things, and that this characteristic is due to its perpetual motion; for things divine, the moon, the sun, the stars, and the whole heavens, are in a state of perpetual motion. Some of the less exact thinkers, like Hippon, have declared the soul to be water. This belief seems to arise from the fact that the seed of all animals is moist. For he rebuts those who say that the soul is blood, on the ground that the seed is not blood. And seed, he says, is primary soul ${ }^{15}$ (trans. W.S. Hett).
\end{abstract}

Hippon's seed model is working here as well as in the former passage about Thales; and Hippon seems to polemize with authors such as Empedocles who claimed the soul to be blood, arguing that the seed is not blood. The difference claimed by Aristotle between the validity of Hippon and Thales - together with the other old philosophers - consequently expelled Hippon from the main line of the later doxographical tradition on the archai, starting with Theophrastus and continuing with Aëtius. But in spite of the Aristotelian denial of the connection between Thales and Hippon in the category of material monism, the liaison with

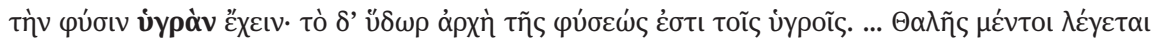

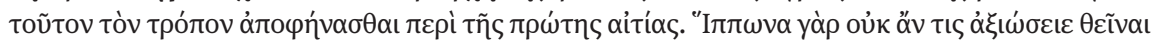

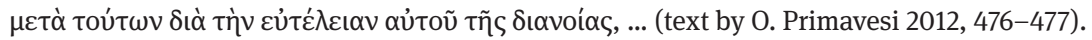

13 Snell 1944, Mansfeld 1985, 122 n. 42 and Mansfeld 1986, but this opinion is now largely accepted (see recently Laks/Most 2016, V 2, 772).

14 Barney 2012, 85-92; already Patzer 1986, 40-41 and Kirk/Raven/Schofield 1983, 91 n. 1.

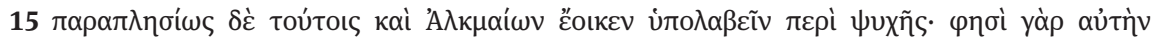

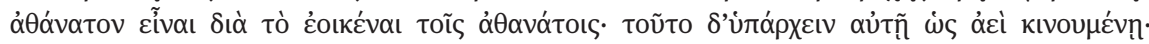

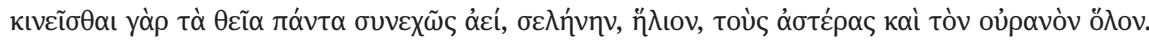

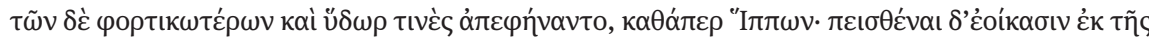

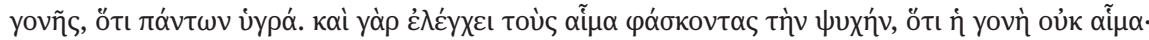

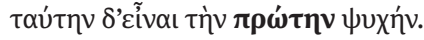


Thales persisted: in other words, the identification of Hippon's first principle with Thales' water (or vice versa) in fact shaped many later sources and modern scholars' opinions, resulting in the twentieth century in the common view that Hippon intended water as his first principle. As a matter of fact, even in Aristotle's passage in Metaphysics, the arguments put forward for Thales' theory about water, which may depend on Hippon, do not explicitly mention water, but always refer to things that are moist. The final sentence of the paragraph, tò $\delta$ ' vँ $\delta \omega \rho$

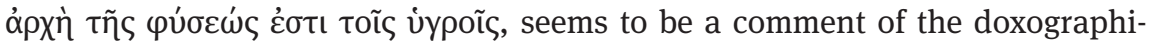
cal source rather than an actual report of Hippon's opinion. On the other hand, another peripatetic source (Alexander of Aphrodisias) says that Hippon's basic principle was "literally" moisture, an opinion which is now largely accepted. ${ }^{16}$

The identification of both Thales and Hippon's first principles as water has also affected how modern scholars have arranged Hippon's fragments. One particularly important example is testimony A10 DK:

Aët. IV 3, 9 (D. 388) Hippon the soul from water. Aristot. de anima A 2, $405 \mathrm{~b} 1$ (s. I 283, 16) b24 [scil. all those who assume pairs of contraries among their first principles also construct the soul from contraries,] while those who suppose the first principle to be one of the pair of contraries such as hot and cold or the like, similarly also suppose the soul to be one of these. Thus they appeal to etymology also; those who identify the soul with heat say that $\zeta \tilde{\eta} v$ (to be alive) is so called for the same reason, but those who identify it with cold maintain that soul ( $\psi v \times \eta$ ) is so called after the cooling process associated with respiration (trans. Hett modified). Philop. z.d.St. 92, 2: One of the opposites is posited by Hippo and Heraclitus. One of them posits the hot; for he says, that principle is fire; the other the cold, positing that water is the principle. Each of these, then, he says, tries to provide an etymological basis about the word soul for his own doctrine, the one saying that living things are said to be alive (zên) because of the boiling (zein), i.e. the hot, the other saying that the name soul (psukhê) is given because of the cold (psukhos), from which it derives its mode of being, since it is the cause of our being cooled through respiration (trans. Ph. van er Eijk)... ${ }^{17}$

16 Manetti 1992, Narcy 2000, 800, and Zhmud 2012, 361.

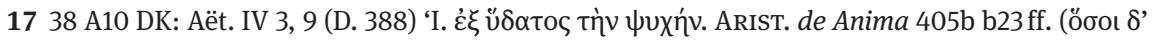

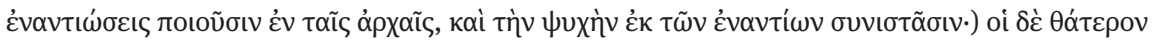

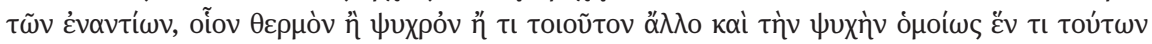

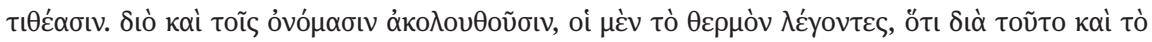

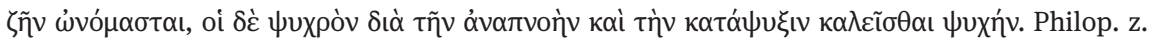

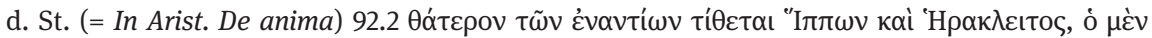

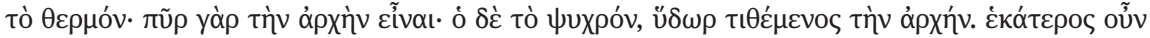

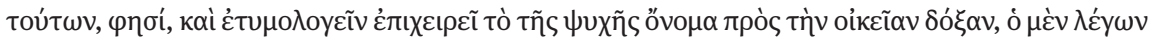

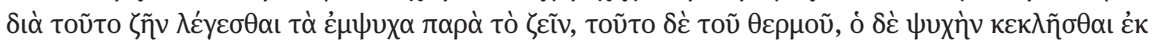

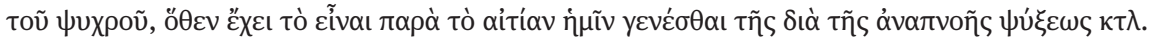
I maintain the graphic setting of Diels' edition, which does not separate the sources. Correctly Lacks and Most did not include Aristotle's and Philoponus' texts into their collection of Hippon's fragments. 
Diels constructs A10 by combining a passage of Aristotle's De Anima and a passage of the corresponding commentary by Iohannes Philoponus. The passage of De Anima selected by Diels does not immediately follow Hippon's mention in 405b 2-3 (see above). Actually, after mentioning Hippon, Aristotle introduces a general consideration about the attributes at that time ascribed to the soul by almost all thinkers, that is, movement, sensation, and incorporeality, and then he analyzes how the nature of the soul in every philosopher is dependent on the general assumption of the first principle claimed by each one (both in the case of a pair of contraries and in the case of one of a pair of contraries). So, I think that in 405b $24 \mathrm{ff}$. Aristotle is not alluding in particular to Hippon, who is not even mentioned, but referring to a general system of four opposite qualities and elements, in which water is qualified as the cold element. It is clear that the ancient philosophers' opinions about the nature of the soul are classified according to Aristotle's interpretive system (four elements and four qualities) rather than correctly represented, as is typical of Aristotle's attitude. Furthermore, as we have seen, the supposed combination of water with cold that Philoponus ascribes to Hippon's theory of the soul contradicts what Aristotle says in Metaphysics. There Aristotle clearly connects the concept of water-humidity with heat and not with cold and above all - water does not seem to be at all part of a system built on contraries. But the commentary of De Anima by John Philoponus, who is influenced not only by the general Aristotelian context but also by later doxography, ${ }^{18}$ introduces the names of Hippon and Heracleitus either as the result of the stratification of the doxography or as his own interpretation of the passage. Diels has totally accepted Philoponus' interpretation of Aristotle, and if we read Diels's text A10 as a whole, we get the impression (via Philoponus) that Hippon's moist-water-soul concept is connected with cold, ${ }^{19}$ while actually this is not attested in any of the more ancient sources. $^{20}$

Another source which draws on the same cultural context, the early history of the Peripatos, is the Anonymus Londiniensis: quoting from a doxography about the causes of disease, explicitly ascribed to "Aristotle", ${ }^{21}$ he gives a very detailed report of Hippon's 'medical' ideas.

18 See the other quotations of Hippon in Philop. In Arist. Gen et corr. 14.2, p. 20630 (Thales and Hippon on water), In Arist. De anima 15.9.10 (Thales and Hippon), and In Arist. Phys. 16. 23.3ff (Thales and Hippon).

19 This opinion is shared by Olivieri 1931, 153, who ascribes what Philoponus says to Aristotle.

20 Philoponus shows similarities with Ps.Hippolitus, Ref. 1,16 (A3 DK = D1 LM).

21 The so-called Anonymus Londiniensis, a medical text preserved by P.Lond. inv. 137, is a papyrus roll which dates to the end of the first century AD: see Manetti 2011, VII-XVII. For a detailed discussion about the doxography, see Manetti 1999, 100-129: the doxography about the causes 


\begin{abstract}
But Hippon of Croton thinks that there is a moisture belonging to us human beings, according to which we perceive and by which we live. Whenever this moisture is in its proper condition, the animal is healthy, but whenever it is dried up, the animal lacks perception and dies. ${ }^{22}$ This is the very reason why old men are dry and lack feeling, because they are without moisture. Analogously, the soles of the feet, lacking moisture, have no feeeling. Summing up, that is what Hippon says. In another book the same author says that the so-called 'moisture' changes through an excess of heat or cold and brings on disease. It changes in the direction of greater moistness or greater dryness, of greater coarseness or greater fineness, or in different ways. With such arguments he accounts for disease, but he does not indicate the diseases that arise $\mathrm{e}^{23}$ (my translation).
\end{abstract}

The phrasing of the whole passage makes it evident that Hippon was not dealing with disease out of professional medical interest. The remark about Hippon not distinguishing single diseases is in fact only prompted by the bias of the doxographical frame ${ }^{24}$ of the author's source. What the Anonymus says about Hippon's "moist" - not water - is confirmed by Alexander of Aphrodisias: "They report that Hippon simply posited moisture as principle in an undifferentiated

of diseases is divided into two camps, 1) thinkers who assume that diseases are produced by the 'residues' of digestion (perittomata) and 2) thinkers who assume that diseases are caused by natural elements of the body (stoicheia): this passage is included in the first part of the doxography. About the ambiguity of the Aristotelian concept of perittoma, ibidem, 113-114.

22 The language used by the Anonymus is a positive clue, I think, for the presence of tò $\zeta \tilde{\omega}$ ov

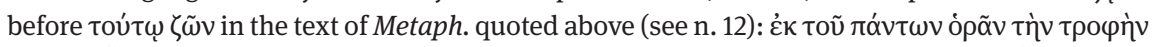

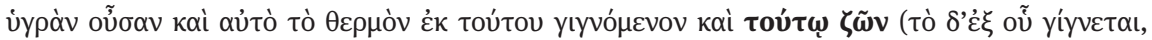

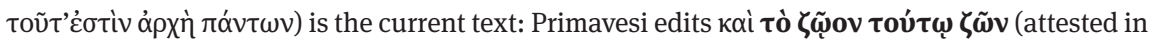
manuscripts of class $\alpha$, see Primavesi 2012, 476).

23 The text was newly edited and commented by Manetti 1992, 455-461, and by Manetti 2011,

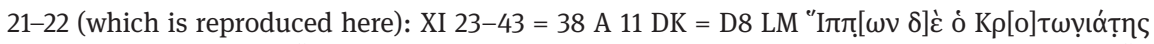

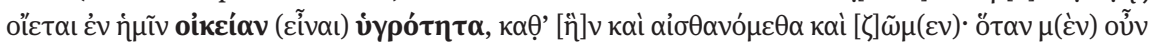

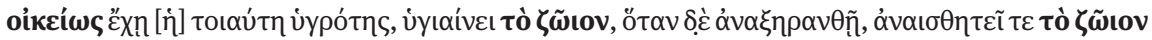

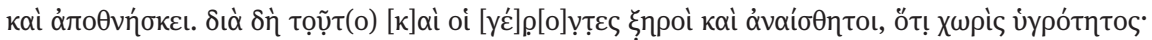

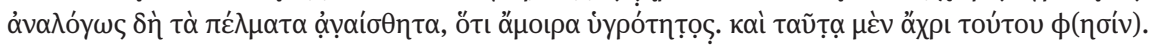

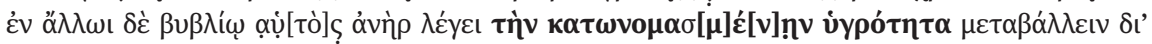

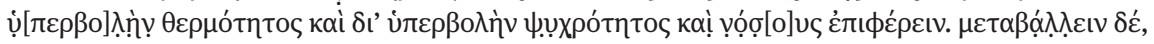

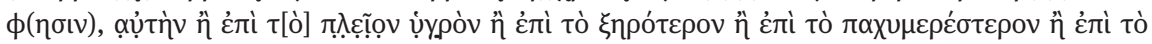

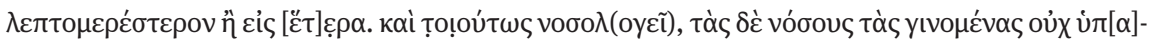

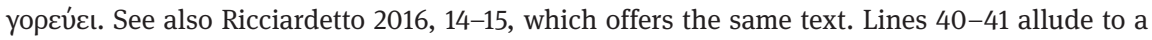
process of varying density similar to the text of Hippon A14 (= Censorin. 6, 4) Ex seminibus autem tenuioribus feminas, ex densioribus mares fieri Hippon adfirmat (Hippon declares that females come from thinner sperm, and males from thicker).

24 Manetti 1999, 101-102: in this frame the presentation of arguments is currently organized into two main points, 1) how diseases arise from perittomata and 2) differences between specific diseases. 
way without clarifying whether it was water, like Thales, or air, like Anaximenes and Diogenes". ${ }^{25}$ One can notice that the Anonymus is literally quoting Hippon's words when he talks of "the so-called moisture". ${ }^{26}$ It is probable that the Aristotelian doxography referred to in the Anonymus Londiniensis had Hippon's text as a direct source.

Hippon's failure to qualify the term "moisture" must have been the result of a precise choice. According the Anonymus' report on Hippon, human health depends on the state of the body's moisture, which is liable to natural and pathological changes. ${ }^{27}$ According to the Aristotelian doxography, this moisture is not a stoicheion, that is, a primary element of the human body, because Hippon is ranked among those thinkers who consider perittomata (the residues of the digestion process) to be the causes of diseases. The concept is typically Aristotelian and the Anonymus never discusses it, taking it for granted. If "moisture" is defined as the oikcí $\alpha$ úypótnৎ of the human body, how can this information be consistent with Aristotle's opinion about Hippon's first principle? This point has produced many doubts in modern scholars about the real nature of Hippon's doxa ${ }^{28}$ in the Anonymus. It is perhaps implicit that this moisture is connected in one way or another with the process of digestion (already described in the previous doxai and taken for granted) and represents a perittoma in a broad sense. ${ }^{29}$ In order to put Hippon's moisture into context and clarify the point, a first area of comparison can be found in some treatises of the Corpus Hippocraticum.

Both in Places in Man and in On Generation - On the Nature of the Child -

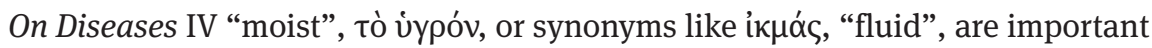
in human physiology. The notion is very general and can also include different types of moisture (bile, phlegm etc.) but the substantivated tò úypóv "moist” is often used as a more general category, like in Places in Man.

25 Alex. Aphr. In Arist. Metaph. A 3, 984a 3, CAG p. 26, 21 ff. (= 38 A6 DK = D3 LM) 'I $\pi \pi \tilde{\omega} v \alpha$

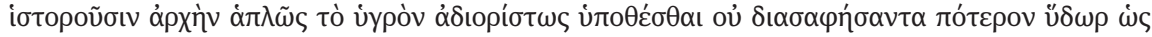

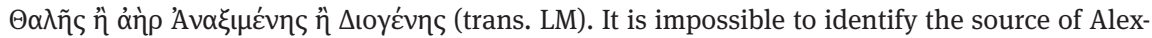
ander, but surely he read something different from Aristotle's text. One may notice that Aristotle uses the same topics when he considers the nature of contraries in Alcmaeon and in the Pythagoreans, remarking that the difference consists of Alcmaeon's not making distinctions (Aristotle

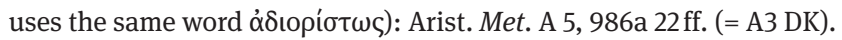

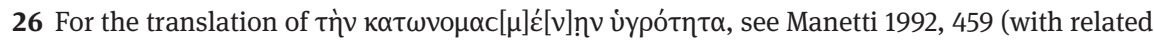
bibliography); see also Zhmud 2012, $361 \mathrm{f}$.

27 Similarly, the Aristotelian doxography in the Anon. Lond. mentions bodily fluids as "moisture" (ن́ypótns). In general, this is also the case in the doxai of other physicians such as Herodicus of Cnidos (V12, 21, 24, 32) and Phasitas of Tenedos (XII 39, 41-43).

28 See the discussion in Manetti 1992, 457-458; Gourevitch 1989, 241 also finds it perplexing that perittoma is not mentioned here and that the idea is not evident in the text.

29 As to the tendency to take for granted what has been said previously, see Manetti 1999, 102. 
1.1 Likewise diseases arise from the whole body indifferently, although the drier component of the body is disposed to become ill and to suffer more, the moist component less. ... 1.2 The cavity, for instance, when material enters it and it does not make a corresponding evacuation downwards, floods the body with the moisture from the ingested food ... This moisture, blocked from the belly, travels en masse to the head ... 3.3 The eye is nourished by the moisture from the brain (trans. P. Potter). ${ }^{30}$

According to the author of Places in Man the fluxes of internal fluids play a central role in causing disease: one may notice first that they are connected with the belly, that is, with the digestion process; second that "fluids" can be negative if the digestion process is imperfect but they are also a natural nutriment of single parts of the body (the eye). In fact, these fluids are composed of phlegm, but in some cases bile is also involved as well as blood and water. The pathological process depends on the four qualities: hot, cold, wet, and dry. But in the quoted passage a more general notion of digestive moisture also emerges as the cause of disease, even though its connection with disease caused by excess of one of the four qualities is never explained. ${ }^{31}$ Nevertheless, it seems to me that a basic substratum exists and persists under the classification of different humours and qualities, that is, a general idea of moisture which is most useful in accounting for many processes. ${ }^{32}$

In On Generation, On the Nature of the Child, and On Diseases IV, which are currently considered to be, if not one work, at least composed by the same author,

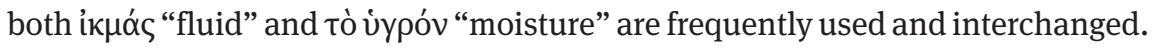
The author says that there are four kinds of moisture or fluid in the human body blood, bile, water, and phlegm - which a person naturally contains. The seed comes from all the moisture of the human body, and also from solid and liquid food. For the most part, the two words íknás and tò ùypóv are used as a collective substitute, a synonym, when the argument indifferently implies one or the other of the single fluids.

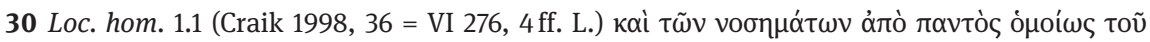

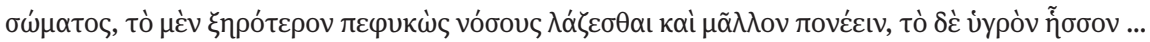

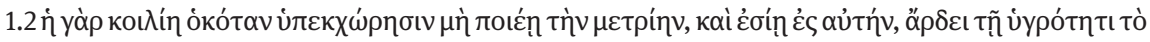

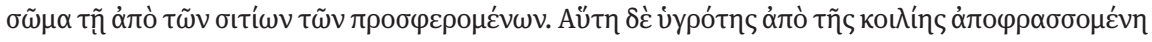

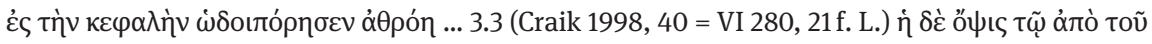

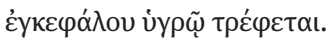

31 Craik 1998, 131.

32 On the marked similarities in conceptual framework and vocabulary between Loc. hom. and many Presocratic thinkers, Hippon included, see Craik 1998, in particular 132-133. 
But there is a section, the so-called "botanical excursus", in Nat. Puer. 22-27,33 where the word ik $\mu \alpha$ ś plays a special role and deserves special attention. ${ }^{34}$ In considering the embryo's nutrition, the author says that the child's state of health depends on the quality of the nutriment it receives from the mother. This statement is illustrated by the analogy of a plant in the earth: the characteristics of the plant depend on those of the earth in which it is planted.

Nat. puer. 22 When a seed is sowed in the earth, it becomes filled with moisture from the earth, for the earth contains within itself all sorts of moistures which nourish what grows in it. A seed, on being filled with moisture becomes inflated and swells, and the potency in the seed, being the lightest part, is compelled by this moisture to congeal. And as this potency congeals from the effects of breath and moisture, leaves are formed and break out through the seed, first sprouting forth to the outside ... Now since (scil. the plant) has arisen from a seed, or ultimately from moisture ... (trans. P. Potter) $)^{35}$

The implications of the context become clearer if we compare this passage with Morb. IV, chapter 34:

Morb. IV 34 For the earth contains within itself innumerable potencies of every kind and it provides each plant that grows in it with the moisture that is specific by birth to that plant and each plant draws from the earth the nutriment that is specific to it (trans. P. Potter). ${ }^{36}$

To sum up, every plant draws from the ground the fluid that it requires and which is specific to itself. The earth has all sorts of moisture that are necessary for every plant, or in other words that every plant has in its nature. The author shows that this hypothesis is true of all plants, whether grown from seeds, cuttings, or grafts. So, chapters 22-27 of On the Nature of the Child develop into a general excursus on plant physiology.

33 See Lonie 1969 and 1981, 211-239.

34 On the analogy between the embryo and the vegetal world, see also Repici 2000, 51-61.

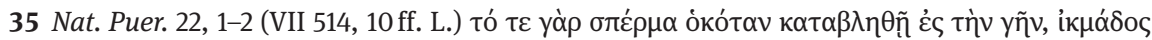

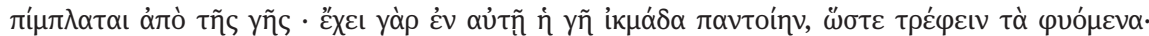

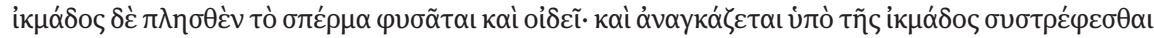

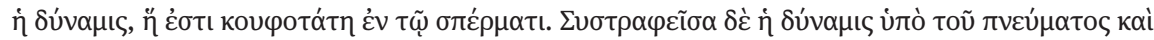

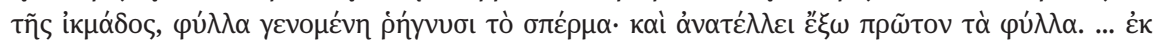

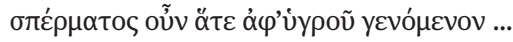

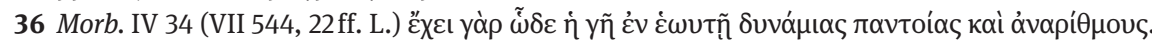

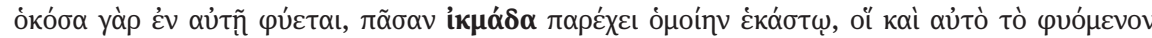

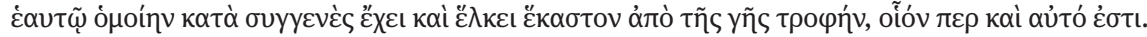


In these passages one can notice that moisture is deeply connected with power ${ }^{37}$ and nutriment. I am not at all suggesting any close connection of these passages with Hippon. I simply want to point out how the very general notion of moisture can be taken into account in illustrating the basic processes of life (most of all vegetal life), without any reference to a theory of primary elements or stoicheia, even if it is accompanied, as in De Natura Pueri, by a specific humour theory. Bearing this in mind, one can better unterstand what permits the Aristotelian doxography in the Anonymus Londiniensis to classify Hippon's moisture as a perittoma. ${ }^{38}$

First of all, however, it is the botanical excursus of On the Nature of the Child that allows us a glimpse of the possible origin of Hippon's moisture. According to Lonie, the botanical excursus lets us know the fifth-century scientific koine. If this is so, we can assume that some issues must have been common topics and we can also add that the botanical parallel suggests a context proper to Hippon's moisture. I think it plausible to attribute a mainly botanical focus, or to possibly identify the role of a botanical model in Hippon's human physiology. The analogy between animal and vegetal life is very ancient and widespread in Greek culture; furthermore, it must not be forgotten that Hippon was certainly concerned with botany, as we know from the first book of Theophrastus' Historia Plantarum, where Hippon appears among the few previous authorities considered worthy of mention. ${ }^{39}$

It has been long remarked that many passages in the first book of Historia Plantarum seem to be modelled after Aristotle's Historia Animalium and indeed the main features of Theophrastus' theoretical framework in the first book of HP are derived from his master. ${ }^{40}$ But Theophrastus also draws greatly on the previous literature on botany, represented by Menestor, Cleidemus, and Hippon: he quotes them in different passages of $H P$ and $C P$ but his debt to them is not always clear. I suspect that it is greater than what said by the occasional explicit quotation of their names. The analogy between the animal and vegetal world which

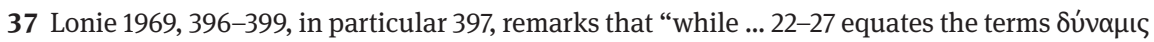

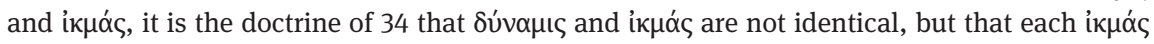

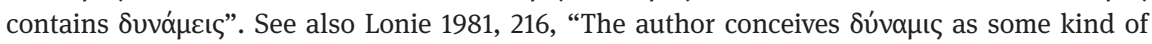
substance".

38 Repici 2000, 24 n., remarks that Aristotle, who constructed an inverse analogy between plants and the human body (the vital functions are reversed: what is high in humans is low in plants), thinks that the function of nutriment is greatly reduced in plants, because they receive already transformed food from the earth, based on chymoi (juice) and heat.

39 It is noteworthy that Strömberg 1937, 19, does not mention Hippon in his short survey of Presocratic botanists.

40 See in general Wöhrle 1985; see also Gotthelf 1988; Repici 2000, 182-188. 
Historia Plantarum often displays is surely influenced by Aristotle's Historia Animalium. Nevertheless, it is evident that it was already widespread in the botanical literature of the fifth century, as we know from Empedocles and have seen in On the Nature of the Child. ${ }^{41}$

Theophrastus starts analysing the differentiae between parts, following his master (one can recognize the Aristotelian language).

Again there are things of which such parts are composed, namely bark, wood and core (in the case of those plants which have it) and these are composed of like parts. Further there are the things that are even prior to these, from which they are derived - moist (íypòv), fibre, veins, flesh: for these are elementary substances - unless one should call them the active principles of the elements: and they are common to all the parts of the plants. Thus the essence and entire material of plants consist in these (trans. LCL corrected). ${ }^{42}$

It is noteworthy that Theophrastus envisages a level of matter prior to the homaeomerous parts he is describing that is a sort of - in his language - elementary substance or active principle of the elements (notice the uncertainty in the evaluation), among which "moist" appears first. That úypòv played a role of its own in botanical science is also clear from another passage of $H P$.

The moist (úypóv) is obvious: some call it simply in all cases 'juice', as does Menestor among others: others give it no special name generally, while in some cases they call it 'juice' and in another case 'gum' ... For we must endeavour to state of what these, as well as the rest, are composed, starting from their elementary constituents. First come moisture and warmth: for every plant, like every animal, has a certain amount of moisture and warmth which essentially belong to it; and if these fall short, age and decay, while, if they fail altogether, death and withering ensue. Now in most plants the moisture has no special name but in some has such a name as has been said ... (trans. LCL corrected). ${ }^{43}$

41 Lonie 1981, 214 ff.; Repici 2000, in particular 69-89.

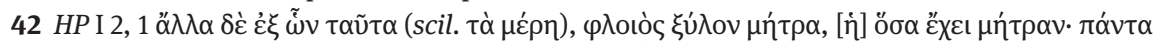

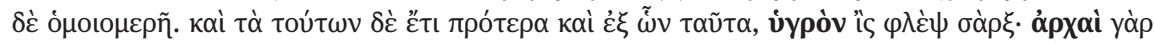

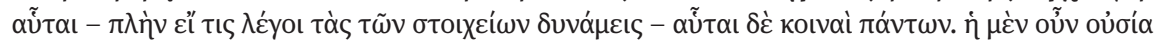

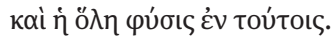

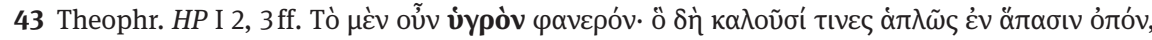

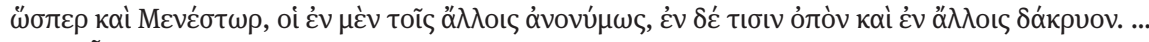

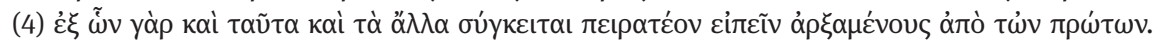

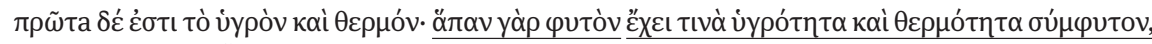

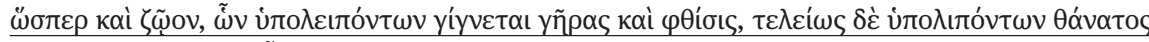

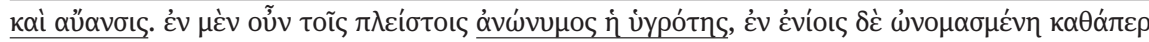

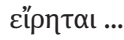


Here Theophrastus is referring to previous authorities and, even if he only mentions Menestor by name, he must have other authors in mind too. The passage reminds us of the arguments used by the Anonymus Londiniensis about Hippon. The connection between youth/heat and humidity vs old age/cold and dry are admittedly common topics, ${ }^{44}$ but here Theophrastus also refers to authors who do not qualify plants' moisture (in a very similar way to the passage in the Anonymus Londiniensis): I think it plausible that Hippon is alluded to in this passage. It is also clear that moist is connected with heat and not with cold. ${ }^{45}$ The theory implicit in this passage (with the addition of warmth) is not far from what we read in the botanical excursus of Nat. Puer., that is, the theory of the specific moisture of every plant. A similar position, of course translated into Aristotelian language, is hinted at by Theophrastus in chapter 12 of $H P$.

Now the moisture (v่ypótņ) of the trees themselves has different features as was said ... To speak generally, all moistures correspond to the special nature of each tree, one might almost add, to that of each plant. For every plant has a certain temperament and composition of its own, which plainly belongs (oikcí $\alpha$ ) to the fruits of each (trans. LCL corrected). ${ }^{46}$

If we compare all the texts I have analyzed, we can draw some conclusions at least: first, that Hippon the botanist was strongly biased by the analogy between the animal and the vegetal world and that the botanical model is predominant in his human physiology; second, as he did not talk at all of water as the basic principle of life, but of moisture, we can imagine the reason why he did not qualify the idea of moisture, because moist - together with heat - is, so to speak, the 'least common denominator' of the (vegetal and animal) living world and the more general it was understood to be, the more useful it was in explaining a variety of issues; third, it seems plausible that Hippon also claimed that plants and analogously human beings (or animals in general) have their own 'specific' natural moisture, which they receive for their growth from the ground (plants) and from their nutriment (human beings and animals), in a similar way to the botanical passage of On the Nature of the Child.

44 For the system of opposite qualities related to aging and decay, see Lonie 1981 as already quoted; Manetti 1992, 461; and Sassi 2009a, 2009b.

45 See what I said about the commentary of Philoponus above.

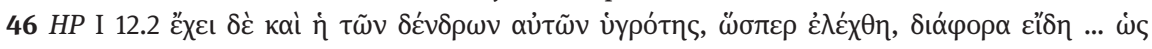

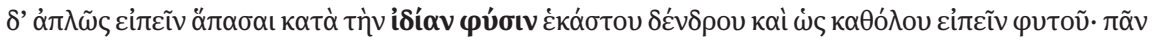

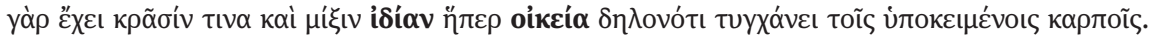
See A 19 (= Theophr. HP I 3.5 and III 2.2). 
If we consider the cultural background I have outlined so far, the expres-

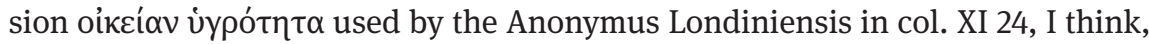
reveals a deeper meaning.

Acknowledgements: Earlier versions of this article have been presented in different seminars in the past years (Berlin, Thessaloniki) but remained unpublished. I am indebted to Francesco Ademollo, Lorenzo Perilli, Valeria Piano, and Amneris Roselli for generously reading the text and thank them for their remarks.

\section{Selected Bibliography}

Barney, R. (2012), “History and Dialectic in Metaphysics A 3 (Metaphysics A 3, 983a24-4b8)", in: C. Steel (ed.), Aristotle's Metaphysics Alpha: Symposium Aristotelicum. With a New Critical Edition of the Greek Text by Oliver Primavesi, Oxford, 69-104.

Centrone, B. (1996), Introduzione ai Pitagorici, Bari-Rome.

Craik, E.M. (ed.) (1998), Hippocrates, Places in Man, ed. and trans. with introd. and comm., Oxford.

Erhard, H. (1939), “Hippo als Biologe”, in: Archiv für Geschichte der Medizin 32, 325-328.

Gemelli Marciano, M.L. (2009), “'Evidentemente il sapiente ha studiato medicina’. Per una revisione dei rapporti fra i cosiddetti presocratici e la medicina ippocratica”, in: Medicina \& Storia 9, 129-156.

Gotthelf, A. (1988), “Historiae I: plantarum et animalium”, in: W.W. Fortenbaugh / R.W. Sharples (eds.), Theophrastean Studies, III, New Brunswick, 100-135.

Kirk, G.S. / Raven, J.E. / Schofield, M. (ed.) (1983), The Presocratic Philosophers, 2nd ed., Cambridge.

Laks, A. / Most, G. (ed.) (2016), Early Greek Philosophy, ed. and trans., V 2, Cambridge, MA.

Lonie, I.M. (1969), “On the Botanical Excursus in De Natura Pueri 22-27”, in: Hermes 97, 391-411.

Lonie, I.M. (1981), The Hippocratic Treatises On Generation, On the Nature of the Child, Diseases. IV, A Commentary, Berlin.

Manetti, D. (1992), “63. Hippo Crotoniates”, in: Corpus dei Papiri Filosofici I**, Florence, 455-461.

Manetti, D. (1999), “'Aristotle' and the Role of Doxography in the Anonymus Londiniensis (PBrLibr inv. 137)", in: P. van der Eijk (ed.), Ancient Histories of Medicine, Leiden-BostonCologne 1999, 95-141.

Manetti, D. (ed.) (2011), Anonymi Londiniensis De medicina, Berlin.

Mansfeld, J. (1985), “Aristotle and Others on Thales, or the Beginning of Natural Philosophy”, in: Mnemosyne 38, 109-129.

Mansfeld, J. (1986), “Aristotle, Plato and the Preplatonic Doxography and Chronography”, in:

G. Cambiano (ed.), Storiografia e dossografia nella filosofia antica, Turin, 1-59.

Narcy, M. (2000), “Hippon de Samos”, in: R. Goulet (ed.), Dictionnaire des philosophes antiques, III, Paris, 799-801. 
Olivieri, A. (1919), “'L'Italiota Hippon”, in: RIGI 3, 1-8 (= Civiltà greca nell'Italia maridonale, Naples 1931).

Pascal, C. (1906), “Ippone e Ippaso”, in: SIFC 14, 1-9.

Patzer, A. (1986), Hippias als Philosophiehistoriker, Freiburg.

Potter, P. (ed.) (1995), Hippocrates. Volume VIII, Cambridge, MA.

Potter, P. (ed.) (2012), Hippocrates. Volume X, Cambridge, MA.

Primavesi, O. (2012), “Aristotle, Metaphysics A. A New Critical Edition with Introduction”, in:

C. Steel (ed.), Aristotle's Metaphysics Alpha: Symposium Aristotelicum, Oxford, 385-516.

Repici, L. (1985), “Il paradigma animale nella botanica di Teofrasto", in: RF 76, 367-398.

Repici, L. (2000), Uomini capovolti. Le piante nel pensiero dei Greci, Bari.

Sassi, M.M. (2008), “Normalità e patologia della vecchiaia nella medicina antica”, in:

L. Repici / C. Crisciani / P.B. Rossi (eds.), Vita longa, Atti Torino, 13-14 June 2008, Florence, 3-18.

Sassi, M.M. (2009a), “Giovane e vecchio, umido e secco, caldo e freddo. Giochi di polarità nel sapere antico", in: S. Beta / F. Focaroli (eds.), Vecchiaia, gioventù, immortalità fra natura e cultura, Fiesole, 11-32.

Sassi, M.M. (2009b), “Normalità e patologia della vecchiaia nella medicina antica”, in:

C. Crisciani / L. Repici / P.B. Rossi (eds.), Vita longa. Vecchiaia e durata della vita nella tradizione medica e aristotelica antica e medievale, Florence, 3-18.

Shapiro, S. (1999), "Hippon the Atheist: the surprisingly intelligent views of Hippon of Samos", in: JAC 14, 111-123.

Snell, B. (1944), “Die Nachrichten über die Lehren des Thales und die Anfänge der griechischen Philosophie- und Literaturgeschichte”, in: Philologus 96, 174-182.

Strömberg, R. (1937), Theophrastea. Studien zur botanischen Begriffsbildung, Gothenburg.

Wöhrle, G. (1985), Theophrasts Methode in seinen botanischen Schriften, Amsterdam.

Zhmud, L. (2012), Wissenschaft, Philosophie und Religion in frühen Pythagoreismus, Berlin $1997=$ Pythagoras and the Early Pythagoreans, Oxford (updated and augmented edition). 